\title{
Prevalence of uropathogens and antimicrobial susceptibility profile in outpatient from Jataí-G0
}

\author{
Prevalência de uropatógenos e perfil de sensibilidade aos \\ antimicrobianos em pacientes ambulatoriais de Jatai-GO
}

Dayane Moraes ; ; Alexandre Braoios; ; Janio Leal Borges Alves³; Rafael Menezes da Costa ${ }^{4}$

\begin{abstract}
Introduction: Urinary tract infections (UTIs) affect people worldwide. Escherichia coli is the main agent of UTI, however the etiology may vary according to the age and sex of the patient. Regional variations in the prevalence and antimicrobial resistance should be considered for therapy choice. Objectives: This study aimed to conduct a survey on the main agents of UTI, and assess the resistance of these microorganisms, during the period of March 2010 to June 2012 in the city of Jataí-GO. Method: A retrospective cross-sectional study were performed, collecting data on the prevalence of uropathogens and their sensitivity profiles which were evaluated by disk diffusion method. Results: During this period, 2,181 urine cultures were evaluated, of which 510 (23.4\%) were positive, predominantly female (81.4\%) and aged between 21 and 64 years old (59.7\%). The most frequently isolated microorganism was E. coli (61\%), followed by Staphylococcus saprophyticus (9.4\%), and Proteus (9.4\%). The prevalence of these bacteria according to the patient sex has suffered a statistically significant change $(\phi<0.05)$. It was possible to detect high resistance rate of $E$. coli to some antibiotics of choice for UTI treatment, such as ampicillin (57.9\%), pipemidic acid (50.5\%), nalidixic acid (48.6\%), and trimethoprim-sulfamethoxazole (44.8\%). Conclusion: These data demonstrate the need to know the reality of each region in order to establish an appropriate empirical therapy, when it is not possible to perform culture and antimicrobial susceptibility testing.
\end{abstract}

Key words: urinary tract infection; Escherichia coli; antimicrobial resistance.

\section{INTRODUCTION}

Urinary tract infection (UTI) ranks second in incidence of bacterial disease, second only to respiratory tract infections ${ }^{(12,25)}$. UTI is defined as an invasion and multiplication of microorganisms in tissue within the urinary tract from the urethra to the kidney. Pathogens can reach the urinary tract in three pathways: ascending, hematogenous, or lymphatic ${ }^{(20)}$. These may results in bacteriuria, cystitis, pyelonephritis, or even acute urethral syndrome ${ }^{(21)}$. They affect individuals at any age, but the groups most affected are male newborns, preschoolers girls, sexually active young woman, men with prostatic obstruction, and elderly ${ }^{(5)}$.
UTIs are, usually, caused by Gram-negative aerobic bacteria, present in the intestinal flora. In acute symptomatic urinary tract infections, Escherichia col $i$ is prevalent, whereas a higher incidence of other enterobacteria with high prevalence of infections caused by Klebsiella sp., Proteus sp., Pseudomonas sp., Enterobacter sp., and Gram-positive from genera Enterococcus sp., and Staphylococcus sp., is observed in chronic infections, or acquired in hospital environment, or related to structural abnormalities of the urinary tract ${ }^{(10,21,23)}$.

The occurrence of pathogens causing UTI varies geographically, and susceptibility profile requires monitoring in order to provide information for therapeutic orientation, especially

First submission on 24/03/14; last submission on $05 / 05 / 14$; accepted for publication on $05 / 05 / 14$; published on 20/06/14

1. Master of Applied Health Science at Universidade Federal de Goiás (UFG)-regional Jataí.

2. PhD in Clinical Analysis at Universidade Estadual Paulista (UNESP)-campus Araraquara; associated professor at UFG-regional Jataí

3. Biotechnology Specialist at Universidade Estadual de Maringá (UEM); master of Health Science at UEM.

4. Master in Pharmacology at Universidade de São Paulo (USP), Ribeirão Preto. 
regarding the empirical antimicrobial therapy. The increase in bacterial resistance to antimicrobial drugs is evident and brings difficulties in controlling urinary tract infections ${ }^{(8,14,24)}$.

Most of studies on isolation and identification of multiresistant bacterial strains is focused on hospitalized patients; however, it is believed that resistant microorganisms can be isolated from individuals in community, due to indiscriminate use of antimicrobials ${ }^{(24)}$. The empirical treatment of UTI is a routine that should be based on regional epidemiologic data, in order to be familiar with the main pathogens and their antimicrobial susceptibility profile. The Infectious Diseases Society of America recommends that therapeutic practice must be based on local epidemiologic data, as a way to periodically reevaluate the empirical therapies employed in that community, as well as to detect possible changes in the susceptibility profile ${ }^{(16,28)}$. Thus, this study aims to help doctors in southwest Goiás, and also provide information that may contribute to the knowledge of UTIs in the country.

\section{OBJECTIVES}

This study aimed to describe the pathogens causing urinary tract infection in outpatients of clinical analysis laboratory at Jataí, in the state of Goiás, and analyze the antimicrobial susceptibility profile of the bacterial species.

\section{METHOD}

This is a retrospective cross-sectional study. The study was performed by collecting data in records of microbiological cultures and susceptibility tests on three clinical analysis laboratories, in Jataí, state of Goiás. Data on urine cultures performed from March 2010 to June 2012 were analyzed. Authorize access to records was warranted by technical experts of the laboratories, and the Project was approved by Research Ethics Committee-Universidade Federal de Goiás (UFG) (protocol 238/11).

Urine cultures were performed in dip slide, according to the laboratory routine, and bacterial identification was performed by conventional biochemical tests.

Susceptibility testing was performed according to antibiotic disk diffusion method. The antimicrobials tested differed among the laboratories participants in the study. Thus, the results for evaluating the susceptibility profile correspond to those antimicrobials tested in all laboratories. The results were expressed as simple percentages.

\section{RESULTS}

In this study, we analyzed the results of 2,181 urine cultures from outpatients in Jataí-G0; patients were 1,791 (82.1\%) female, and $390(17.9 \%)$ male. From the total urine cultures performed, $510(23.4 \%)$ showed colony counts equal or greater than $10^{5}$ $\mathrm{UFC} / \mathrm{ml}$ of urine. Patients with positive urine culture were mostly female (81.4\%). The age of the patients who underwent urine microbiological test varied from 0 to 97 years, and was prevalent in the age group 21-64 years (59.7\%). Analyzing only patients whose urine culture was positive, there were also a prevalence of individuals in this age group (59.2\%), as can be observed in Table $\mathbf{1}$.

TABLE 1 - Positivity of urine culture according to patient's sex

\begin{tabular}{cccc}
\hline \multirow{2}{*}{$\begin{array}{c}\text { Age group } \\
\text { (years) }\end{array}$} & \multicolumn{3}{c}{ Patients with positive urine culture } \\
\cline { 2 - 4 } & Female & Male & Total $n(\%)$ \\
\hline$<1$ & 27 & 20 & $47(9.2 \%)$ \\
$1-12$ & 29 & 17 & $46(9.0 \%)$ \\
$13-20^{*}$ & 14 & 4 & $18(3.6 \%)$ \\
$21-64^{*}$ & 276 & 26 & $302(59.2 \%)$ \\
$>64^{*}$ & 69 & 28 & $97(19.0 \%)$ \\
Total & 415 & 95 & $510(100 \%)$ \\
\hline
\end{tabular}

${ }^{*} \mathrm{p}<0.05$.

The UTIs frequency, according to patient's gender was not statistically significant in individuals under 12 years of age. Above this age, all age groups showed statistically significant difference between genders.

From 510 clinical samples with bacterial growth consistent to infection, $E$. coli was the most prevalent specie, representing $61 \%$ of bacteria strain. As shown in Table 2, Proteussp. and Staphylococcus saprophyticus showed the second highest prevalence (9.4\%). Analyzing the uropathogens prevalence, according to patient gender, it is possible to observe significant differences in the $E$. coli, $S$. saprophyticus, Proteus sp., Klebsiella sp. e Enterobacter sp. results.

In relation to susceptibility profile, this study showed elevated resistance rate to the antimicrobials more commonly used in UTI treatment (Table 3). E. coli strains showed high resistance levels to ampicilin (57.9\%), pipemidic acid (50.5\%), nalidixic acid (48.6\%), and trimethoprim-sulfamethoxazole (44.8\%).

\section{DISCUSSION}

Urinary tract infection is a very common disorder that affects millions of people each year. It is one of the main reason that leads people to seek medical aid ${ }^{(2)}$. 
TABLE 2 - Frequency of microorganisms isolated at clinical analysis laboratories in Jataí, from March 2010 to June 2012

\begin{tabular}{|c|c|c|c|c|c|c|}
\hline \multirow{3}{*}{ Bacterium } & \multicolumn{4}{|c|}{ Sex } & \multirow{2}{*}{\multicolumn{2}{|c|}{ Total }} \\
\hline & \multicolumn{2}{|c|}{ Female } & \multicolumn{2}{|c|}{ Male } & & \\
\hline & $n$ & $\%$ & $n$ & $\%$ & $n$ & $\%$ \\
\hline E. coli* & 256 & 61.7 & 55 & 57.9 & 311 & 61.0 \\
\hline S. saprophyticus* & 48 & 11.6 & 0 & 0.0 & 48 & 9.4 \\
\hline Proteus sp. * & 38 & 9.2 & 10 & 10.5 & 48 & 9.4 \\
\hline Klebsiella sp.* & 22 & 5.3 & 10 & 10.5 & 32 & 6.3 \\
\hline Enterococcus sp. & 10 & 2.4 & 8 & 8.4 & 18 & 3.5 \\
\hline Enterobacter sp.* & 13 & 3.1 & 4 & 4.2 & 17 & 3.3 \\
\hline S. aureus & 7 & 1.7 & 6 & 6.3 & 13 & 2.5 \\
\hline Citrobacter sp. & 5 & 1.2 & 2 & 2.1 & 7 & 1.4 \\
\hline Streptococcus beta-hemolytic & 5 & 1.2 & 0 & 0.0 & 5 & 1.0 \\
\hline Providencia sp. & 5 & 1.2 & 0 & 0.0 & 5 & 1.0 \\
\hline Pseudomonas sp. & 4 & 1.0 & 0 & 0.0 & 4 & 0.8 \\
\hline Edwardsiella sp. & 2 & 0.5 & 0 & 0.0 & 2 & 0.4 \\
\hline Total & 415 & 100 & 95 & 100 & 510 & 100 \\
\hline
\end{tabular}

${ }^{*} \mathrm{p}<0.05$.

According to the literature, UTIs affect mainly women ${ }^{(2)}$; this study also meet this result. The high prevalence in female is justified due to hormonal effects, behavioral factors, and woman anatomic characteristics, since their urethra is short and the anus is near to the vaginal vestibule, which favor urinary tract infections ${ }^{(13,20,21)}$.

Escherichia coli is a microorganism belonging to normal human intestinal flora, and may cause extra intestinal infections ${ }^{(9)}$. The higher prevalence of $E$. coli as community urinary tract infection agent is expected and reported in epidemiologic studies worldwide. This microorganism was reported in $65.9 \%{ }^{\left({ }^{(}\right)}$and $75 \%{ }^{(4)}$ studies carried out in the State of São Paulo. In Santa Catarina and Minas Gerais, the prevalence found was $79.9 \%{ }^{(23)}$ and $72 \%{ }^{(25)}$, respectively. The increased $E$. coli prevalence found as an UTI agent is used to orientate/guide the empiric treatment, in which the recommendation is especially based on the susceptibility profile of Gram-negative bacteria, mainly $E$. $\operatorname{coli}^{(19)}$. However, despite the higher prevalence of this microorganism, rates can change dramatically; consequently, they will interfere in the therapeutic used. A study published in 2010, performed in Campina Grande - $\mathrm{PB}$, a significant lower percentage of $E$. coli $(48,2 \%)$ was found ${ }^{(9)}$.

In other countries this variation in the major uropathogens prevalence can also be observed. An Indian study ${ }^{(26)}$ showed E. coli prevalence of $48.3 \%$; other studies showed prevalence of $71.3 \%$ in Turkey ${ }^{(1)}$ and $77.5 \%$ in Belgium ${ }^{(3)}$.
TABLE 3 - Resistance profile of major uropathogens isolated in outpatients samples in Jataí, from March 2010 to June 2012

\begin{tabular}{|c|c|c|c|}
\hline \multirow[b]{2}{*}{ Antibiotic } & \multicolumn{3}{|c|}{ Isolated species } \\
\hline & $\begin{array}{l}\text { E. } \operatorname{coli}(311) \\
\quad n(\%)\end{array}$ & $\begin{array}{c}\text { Staphylococcus sp. (61) } \\
n(\%)\end{array}$ & $\begin{array}{c}\text { Proteus sp. (48) } \\
n(\%)\end{array}$ \\
\hline Nalidixic acid & $151(48.6)$ & NT & $26(54.2)$ \\
\hline Pipemidic acid & $157(50.5)$ & NT & $22(45.8)$ \\
\hline Amicacin & $63(20.2)$ & NT & $4(8.3)$ \\
\hline Ampicilin & $180(57.9)$ & NT & $18(37.5)$ \\
\hline Cafalexin & $134(43.1)$ & NT & $22(45.8)$ \\
\hline Cefotaxime & $29(9.3)$ & NT & $4(8.3)$ \\
\hline Cefoxitin & 37 (14.3) & $7(11.5)$ & $11(22.9)$ \\
\hline Ceftriaxone & $39(12.5)$ & NT & 7 (14.6) \\
\hline Cefazolin & 99 (31.8) & NT & $22(45.8)$ \\
\hline Cefuroxime & $60(19.2)$ & NT & $18(37.5)$ \\
\hline Ciprofloxacin & $94(30.2)$ & $9(14.7)$ & $11(22.9)$ \\
\hline Clindamicin & NT & $15(24.6)$ & NT \\
\hline Eritromicin & NT & $15(24.6)$ & NT \\
\hline Gentamicin & $45(14.5)$ & $6(9.8)$ & $11(22.9)$ \\
\hline Nitrofurantoin & $81(26.0)$ & $3(4.9)$ & $26(54.2)$ \\
\hline Norfloxacin & $109(25.0)$ & $10(16.4)$ & 7 (14.6) \\
\hline Oxacillin & NT & $4(6.6)$ & NT \\
\hline Penicillin & NT & $30(49.2)$ & NT \\
\hline Rifampicin & NT & $19(31.1)$ & NT \\
\hline $\begin{array}{l}\text { Trimethoprim- } \\
\text { sulfamethoxazole }\end{array}$ & $139(44.8)$ & $22(36.1)$ & $29(60.4)$ \\
\hline Tetraciclin & $131(42.1)$ & $6(9.8)$ & $18(37.5)$ \\
\hline $\begin{array}{l}\text { Ticarcillin }+ \\
\text { clavulanato }\end{array}$ & $7(2.2)$ & $1(6.6)$ & $3(6.2)$ \\
\hline
\end{tabular}

NT: not tested.

In the literature, data on other pathogens prevalence show large variation, while in this study, the most prevalent uropathogens, excepting $E$. coli, were S. saprophyticus (9.4\%) and Proteus sp. (9.4\%); other studies suggest Klebsiella sp. as the second most prevalent ${ }^{(7,27)}$. Otherwise, Beraldo-Massoli et al.$^{(4)}$ found prevalence of $11 \%$ to Enterobacter sp., while Queiroz and Felício ${ }^{(2)}$ found similar results to those here observed.

In addition to data regarding the causative agent to UTI, for establishing an efficient empiric therapy, it is important to consider patient the age and sex, as regards to antimicrobials pharmacological properties and patient clinical history, but also to the prevalence differences of microbial agents in each region. In a study conducted by den Heijer et al., E. coli prevalence as UTI causative agent was significantly different between men $(51 \%)$ and women $(72 \%)^{(11)}$. Otherwise, these authors found 
significant differences in susceptibility profile of isolated strains between male and female patients, demonstrating that empirical treatment should consider this aspect. Another study demonstrates significant differences in UTI etiology, according to patient sex and age. Thus, Proteus sp. showed significant higher prevalence among men, and $E$. coli prevalence among infants was significantly lower ${ }^{(18)}$.

These last two antimicrobials are extensively used in UTI empirical treatment, but data demonstrated that significant number of $E$. coli are resistant. These data should be used to discourage the administration of these drugs for empirical treatment.

Naber suggest that in regions which the rate of resistance to a given antimicrobial is greater than $10 \%$ to $20 \%$, this drug should not be used empirically ${ }^{(22)}$. Quinolones are widely used drugs in UTI treatment, and its administration is indicated for treatment when ther is a high resistant rate to trimethoprimsulfamethoxazole ${ }^{(16,28)}$, but data here obtained, also reveal high resistance rate to this antimicrobial group: 48.6\% to nalidixic acid, and $30.2 \%$ to ciprofloxacin. This finding indicates that the use of these drugs should be careful, and the empirical use should be discouraged, since its use easily select resistant strains ${ }^{(17)}$.

Resistance to fluoroquinolones has been reported in several regions, this is due to its extensive use. Aypak et al. found prevalence of $41.1 \%$ to fluoroquinolones strains resistant, in a study carried out in Turkey ${ }^{(1)}$. Guajardo-Lara et al., in a study performed in Mexico, found $24.7 \%$ of resistance to ciprofloxacin ${ }^{(15)}$. Similar resistance percentage (23.5\%) was also reported in India ${ }^{(26)}$.

In Brazil, this situation is not different. Silveira et al., in a study performed in Uberaba-MG, found trimethoprimsulfamethoxazole (48\%) and ciprofloxacin (25\%) resistance rates similar to those here observed ${ }^{(27)}$. Otherwise, in other regions of the country, fluoroquinolones resistance does not reach such high rates. In a study carried out in Campina Grande$\mathrm{PB}^{(9)}$, trimethoprim-sulfamethoxazole resistance rate (41.9\%) was similar to that found here, but the $E$. coli isolated strains showed low resistance to ciprofloxacin and norfloxacin $(8.2 \%$ for both). Thus, these drugs represent an excellent therapeutic choice in that region.

\section{CONCLUSION}

Due to high levels of resistance found to first choice drugs, empirical therapy became a difficult clinical decision. Therefore, it is important to know the epidemiologic and resistance aspects of main pathogens in each region, in order to help in use of appropriate therapy to regional circumstances.

\section{RESUMO}

Introdução: Infecções do trato urinário (ITU) afetam pessoas em todo o mundo. Escherichia coli é o principal agente de ITU, no entanto a etiologia pode variar de acordo com o sexo e a idade do paciente. Variações regionais quanto à prevalência e à resistência aos antimicrobianos devem ser consideradas para a escolha terapêutica. Objetivos: Este trabalho teve por objetivo realizar um levantamento sobre os principais agentes de ITU e avaliar o perfil de resistência desses microrganismos no período de março de 2010 a junho de 2012, na cidade de Jatai-GO. Método: Estudo retrospectivo de corte transversal realizado por meio de coleta de dados sobre a prevalência de uropatógenos e seus perfis de sensibilidade avaliados pelo método da difusão. Resultados: Neste período, foram realizadas 2.181 uroculturas, das quais $510(23,4 \%)$ apresentaram resultado positivo, sendo predominantemente do sexo feminino (81,4\%) e com idade entre 21 e 64 anos de idade (59,7\%). o microrganismo mais frequentemente isolado foi E. coli (61\%), seguido de Staphylococcus saprophyticus (9,4\%) e Proteus (9,4\%). A prevalência dessas bactérias, de acordo com o sexo do paciente, sofreu variação estatisticamente significativa $(\mathrm{p}<0,05)$. Foi possivel constatar elevada taxa de resistência de E. coli para alguns antimicrobianos de primeira escolba para tratamento de ITU, como ampicilina (57,9\%), ácido pipemídico (50,5\%), ácido nalidíxico (48,6\%) e sulfazotrim (44,8\%). Conclusão: Esses dados demonstram a necessidade de se conhecer a realidade de cada região a fim de se estabelecer uma terapia empírica adequada, quando não for possível a realização da cultura e do antibiograma.

Unitermos: infecção urinária; Escherichia coli; resistência aos antimicrobianos. 


\section{REFERENCES}

1. AYPAK, C. et al. Empiric antibiotic therapy in acute uncomplicated urinary tract infections

and fluoroquinolone resistance: a prospective observational study. Ann Clin Microbiol

Antimicrob, v. 8, 2009. Disponível em: <http://www.ann-clinmicrob. com/content/8/1/27>. Acesso em: 14 dez. 2013.

2. BAIL, L.; ITO, C. A. S.; ESMERINO, L. A. Infecção do trato urinário: comparação entre o perfil de susceptibilidade e a terapia empírica com antimicrobianos. Rev Bras Anal Clin, v. 38, n. 1, p. 51-6, 2006.

3. BECKER, D. et al. Evolution of bacterial susceptibility pattern of Escherichia coli in uncomplicated urinary tract infections in a country with high antibiotic consumption: a comparison of two surveys with a 10 years interval.J Antim Chemother, v. 62, p. 364-8, 2008.

4. BERALDO-MASSOLI, M. C. et al. Prevalência de infecções urinárias em pacientes atendidos pelo sistema único de saúde e sua suscetibilidade aos antimicrobianos. Medicina, v. 45, n. 3, p. 318-21, 2012.

5. BRANDINO, B. A. et al. Prevalência e fatores associados à infecção do trato urinário. NewsLab, ed. 83, p. 166-76, 2007.

6. BRAOIOS, A. et al. Infecções do trato urinário em pacientes não hospitalizados: etiologia e padrão de resistência aos antimicrobianos. J Bras Patol Med Lab, v. 45, n. 6, p. 449-56, 2009.

7. CAMARGO, C. B. S. et al. Infecção por vias urinárias na comunidade de Ribeirão Preto-SP: etiologia, sensibilidade bacteriana a antimicrobianos e implicações terapêuticas. Medicina (Ribeirão Preto), v. 35, p. 173-8, 2002.

8. CASTRO, M. S. et al. Tendências na utilização de antimicrobianos em um hospital universitário, 1990-1996. Rev Saúde Publ, São Paulo, v. 36, n. 5, 2002. Disponível em: <http:/www.fsp.usp.br/rsp> . Acesso em: 26 mar. 2014.

9. COSTA, L. C. et al. Infecções urinárias em pacientes ambulatoriais: prevalência e perfil de resistência aos antimicrobianos. Rev Bras Anal Clin, v. 42, n. 3, p. 175-80, 2010.

10. DANIEL, F. et al. Multidrug-resistant urinary tract isolates of Escherichia coli: prevalence and patient demographics in the United States in 2000. Antimicrob Agents Chemoter, v. 45, n. 5, p. 1402-6, 2001.

11. den REIJER et al. The importance of gender-stratified antibiotic resistance surveillance of unselected uropathogens: a dutch nationwide extramural surveillance study. PLoS One, v. 8, n. 3, p. e60497, doi: 10.1371/journal.pone.0060497, 2013.

12. FUNFSTUCK, R.; OTT, W.; NABER, K. G. The interaction of urinary tract infection and renal insufficiency. Int J Antimicrob Agents, v. 29, p. 72-7, 2006. Disponivel em: <http:/www.ijaaonline.com/>. Acesso em: 26 mar. 2014.

13. GIBERLING, T. L. Urologic diseases in America project: trends in resourse use for urinary tract infections in women. J Urol, v. 173, n. 4, p. 1281-7, 2005.

14. GORDON, K. A.; JONES, R. N. Susceptibility patterns of orally administered antimicrobials among urinary tract infection pathogens from hospitalized patients in North America: comparison report to Europe and Latin America. Results from the SENTRY Antimicrobial Surveillance Program (2000). Diagn Microbiol Infect Dis, v. 45, p. 295-301, 2003.

15. GUAJARDO-LARA, C. E. et al. Resistencia antimicrobiana en la infección urinaria por Escherichia coli adquirida en la comunidad. ¿Cuál antibiótico voy a usar? Salud Publica Mexico, v. 51, n. 2, p. 155-8, 2009.

16. GUPTA, K. et al. International clinical practice guidelines for the treatment of acute uncomplicated cystitis and pyelonephritis in women: a 2010 Update by the Infectious Diseases Society of America and the European Society for Microbiology and Infectious Diseases. Clin Infect Dis, v. 52, n. 5, p. e103-e120, 2011.

17. KAHLMETER, G. et al. Non-hospital antimicrobial usage and resistance in community-acquired Escherichia coli urinary tract infection. J Antimicrob Chemother, v. 52, p. 1005-10, 2003.

18. LO, D. S. et al. Infecção urinária comunitária: etiologia segundo idade e sexo.J Bras Nefrol, v. 35, n. 2, p. 93-8, 2013.

19. MARQUUES, M. L. et al. Aumento da resistência bacteriana no controle de infecção urinária adquirida na comunidade. Sinopse de Urologia, v. 9 , n. 5, p. 122-3, 2005.

20. MORA, J. F. et al. Perfil dos pacientes com infecções do trato urinário diagnosticados no município de Flor do Sertão-SC. Rev Bras Anal Clin, v. 40, n. 4, p. 321-3, 2008.

21. MULLER, E. V.; SANTOS, D. F.; CORREA, N. A. B. Prevalência de microrganismos em infecções do trato urinário de pacientes atendidos no laboratório de análises clínicas da Universidade Paranaense-UmuaramaPR. Rev Bras Anal Clin, v. 40, n. 1, p. 35-7, 2008.

22. NABER, K. G. Treatment options for acute uncomplicated cystitis in adults.J Antimicrob Chemother, v. 46, Suppl 1, p. 23-7, 2000.

23. OLIVEIRA, F. A.; NOGUEIRA, K. S. Resistência a fluoroquinolonas em Escherichia coli isoladas em cultura de urina. Rev Bras Anal Clin, v. 43 , n. 2, p. 152-4, 2011.

24. POLETTO, K. Q.; REIS, C. Suscetibilidade antimicrobiana de uropatógenos em pacientes ambulatoriais na cidade de Goiânia, GO. Rev Soc Bras Med Trop, v. 38, n. 5, p. 416-20, 2005.

25. QUEIROZ, C. A.; FELíCIO, V. P. T. Infeções urinárias de origem bacteriana em pacientes atendidos em laboratórios de análises clínicas de Presidente Olegário-MG. NewsLab, v. 101, p. 106-11, 2010.

26. SHARIFF, A. R. The antibiotic susceptibility patterns of uropathogenic Escherichia coli, with special reference to the fluoroquinolones. J Clin Diagn Res, v. 7, n. 6, p. 1027-30, 2013.

27. SILVEIRA, S. A. et al. Prevalência e suscetibilidade bacteriana em infecções do trato urinário de pacientes atendidos no Hospital Universitário de Uberaba. RBAC, v. 42, n. 3, p. 157-60, 2010.

28. WARREN, J. W. et al. Guidelines for antimicrobial treatment of uncomplicated acute bacterial cystitis and acute pyelonephritis in women. Clin Infect Dis, v. 29, p. 745-58, 1999.

\section{MAILING ADDRESS}

Alexandre Braoios

Rua 25, 375, Quadra 36, Lote 23; Residencial das Brisas; CEP: 75803-495; Jataí-G0, Brazil; e-mail: ab31@uol.com.br. 